\title{
Danube River Discharge at Bezdan Gauging Station (Serbia) and its correlation with Atmospheric Circulation Patterns
}

\author{
Dragan DolinajA ${ }^{*}$, Igor Leščešen ${ }^{A}$, Milana Pantelićc ${ }^{A}$, Marko Urošev ${ }^{B}$, Dragana Milijašević Joksimovićc \\ Received: August 06, 2018 | Revised: February 14, 2019 | Accepted: February 18, 2019
}

DOI: 10.5937/gp23-18514

\begin{abstract}
For understanding hydroclimatological process chain it is crucial to identify relations between largescale climatic circulations and river discharge. The Danube is one of the most important European waterways, flowing 2.857 kilometers across the Europe and with $817.000 \mathrm{~km}^{2}$ basin. Danube River average and maximum discharges are correlated with eight atmospheric circulation patterns indices: $\mathrm{AOi}, \mathrm{EAi}$, EA/WRi, ENSOi, MOi, NAOi, SCANDi and WeMOi in 65 years period at the Bezdan gauging station in Serbia. Obtained results showed that precipitation, MOi and WeMOi have constant and dominant influences on Danube River average discharge at Bezdan gauging station, while maximum discharge is mainly influenced by precipitation and MOi. All registered correlations are positive.
\end{abstract}

Keywords: atmospheric circulation patterns; trends; Danube River; discharge; Serbia

\section{Introduction}

Identifying relationships between large-scale climatic circulations and river basin-scale precipitation as well as discharge provides insight into understanding the hydroclimatological process chain (Kingston et al., 2009). Statistically significant empirical climate linkages could be exploited in predicting precipitation and river flow anomalies at seasonal timescales if combined with accurate seasonal predictions of the driving large-scale climatic circulations. Such long-term hydrological predictions are important to help improve advanced planning of water resources and increase human preparedness for hydrological extremes, including floods and droughts (Wedgbrow et al., 2002). This is an important challenge because hydrological extremes are expected to become more commonplace in a changing climate (Kundzewicz et al., 2007). Studies investigating relationships between large-scale climatic circulations and precipitation as well as river flow, use atmospheric indices that summarise the main modes of atmospheric variability over a particular region and their time-series are freely-downloadable (Lavers et al., 2011). Numerous studies proved the links between weather, hydrology and atmospheric circulation patterns. The North Atlantic Oscillation (NAO), which refers to the redistribution of atmospheric mass between the subtropical Atlantic and the Arctic (Hurrell et al., 2003), is considered the most significant mode of climate variability in the North Atlantic region (Murphy \& Washington, 2001). Changes in the NAO phase, as characterised by the NAO index, have been associated with variations in the frequency and strength of the surface westerly winds over Europe, which influences precipitation occurrence (Fowler et al., 2003; Uvo, 2003). The El Nino-Southern Oscillation (ENSO) influences sig-

A Climatology and Hydrology Research Center, Faculty of Sciences, University of Novi Sad, Trg Dositeja Obradovića 3, 21000 Novi Sad, Serbia; igorlescesen@yahoo.com

B Geographical Institute "Jovan Cvijić", Serbian Academy of Sciences and Arts, Djure Jakšića 9, 11000 Belgrade, Serbia

* Corresponding author: Dragan Dolinaj, dragan.dolinaj@dgt.uns.ac.rs 
nificantly the precipitation over Europe (Rimbu et al., 2004). Significant influence of Western Mediterranean Oscillation (WeMO), NAO and Mediterranean Oscillation (MO) on precipitation in Central Europe is observed (Milošević et al., 2015). Furthermore, significant correlations between the mean annual maximum temperatures and the East Atlantic Oscillation (EA), Arctic Oscillation (AO) and the Scandinavian Oscillation (SCAND) are indicated (Milošević et al., 2015, Milošević et al., 2017). River discharge and its extremes have been correlated with atmospheric circulation indices in numerous studies and books (Bomin \& Shuqing, 1994; Caspary, 1995; Fan, 2005; Peterson et al., 2002; Peterson et al., 2013). Rimbu et al. (2002) analyzed the influence of NAOi on Danube River flow at the lower basin stations for the period 1931-95. Results of this study indicated strong correlation between NAOi and decadal variability of Danube River flow in the lower basin. In the next study, Rimbu et al. (2004) analyzed the influence of NAOi and ENSOi on Danube River flow variability. According to this study, significant positive correlations have been established between NAOi, ENSOi and Danube flow variability (especially maximum). Higher correlations were observed between maximum flow variability and NAOi during colder part of the year and ENSOi during warmer part of the year. However, relationships between circulation pattern indices and Danube River discharge in central basin (Pannonian plain) have not been well identified.
The main aim of this paper is to analyze temporal variability of annual maximum discharge $\left(\mathrm{Q}_{\max }\right)$, average discharge $\left(\mathrm{Q}_{\text {avg }}\right)$ and precipitation data on Bezdan gauging station at Danube River in Serbia (Central Danube basin) and to correlate it with indices of the atmospheric circulation patterns influencing Central European region: Arctic Oscillation index (AOi), East Atlantic Oscillation index (EAi), East Atlantic/Western Russia Oscillation index (EA/WRi), El Nino Southern Oscillation index (ENSOi), Mediterranean Oscillation index (MOi), North Atlantic Oscillation index (NAOi), Scandinavian Oscillation index (SCANDi) and Western Mediterranean Oscillation index (WeMOi).

In Central Danube River basin, Danube River flows through Hungary, Serbia and Croatia. Bezdan gauging station is positioned in Serbia, close to SerbiaHungary-Croatia border triangle.

Results of this analysis will indetify possible links between atmospheric patterns and Danube flow extremes in central Danube River basin. Study results can help in predicting extreme Danube flow scenarios in Serbia (SRB) and Croatia (CRO) river section of importance to cities: Apatin (SRB), Osjek (CRO), Vinkovci (CRO), Vukovar (CRO), Bačka Palanka (SRB), Novi Sad (SRB), Belgrade (SRB), Pančevo (SRB) and Smederevo (SRB). Furthermore, obtained results can represent input data for the risk management studies in the Central Danube River basin.

\section{Data and methods}

The primary research subject analyzed in this study is the variation in Danube river flow. The Danube is one of the most important European waterways, flowing 2.857 kilometers across the continent from the Schwarzwald (Black Forest) Mountains in Germany down to the Black Sea. The Danube basin extends to $817.000 \mathrm{~km}^{2}$ with many countries sharing the Danube catchment area (Rimbu et al., 2004). The time series of Danube river discharge used in this study are recorded at Bezdan gauging station $\left(45.84^{\circ} \mathrm{N} ; 18.97^{\circ} \mathrm{E}\right)$. Precipitation data were obtained from Sombor meteorological station that is geographically closest precipitation station to Bezdan gauging station in Serbia. The database was provided by the Republic Hydrometeorological Service (RHMS) from Belgrade, Serbia. The streamflow and precipitation monthly data covers the period from 1951 to 2014.

Our study is focused on the exploration of the relations between the atmospheric circulation patterns influencing Central European region and Danube discharge variability recorded at Bezdan gauging station. Eight atmospheric circulation patterns indices

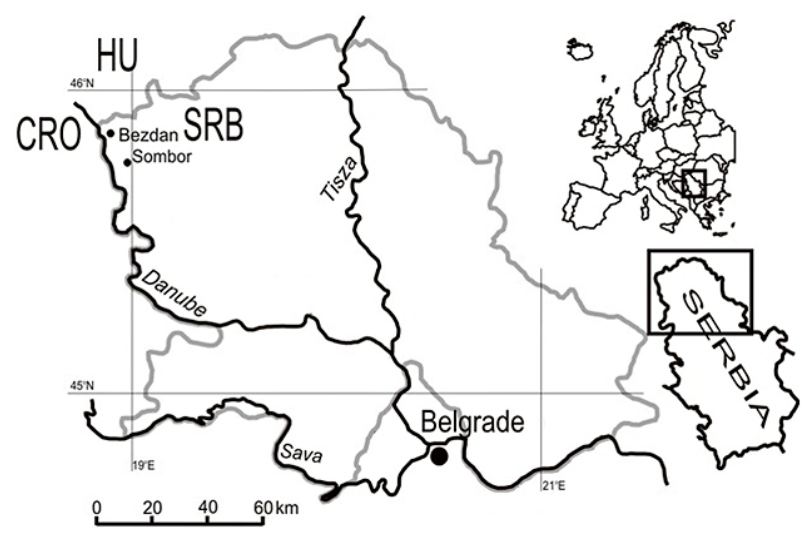

Figure 1. Spatial position of Bezdan gauging station

were used: AOi, EAi, EA/WRi, ENSOi, MOi, NAOi, SCANDi and WeMOi. Monthly values of AOi, EAi, EA/WRi, ENSOi, SCANDi and NAOi were obtained from the National Oceanic and Atmospheric Association (NOAA) Climate Prediction Center (CPC) Website (https://www.cpc.ncep.noaa.gov/products/precip/ CWlink/daily_ao_index/teleconnections.shtml) for the period 1951-2014. Daily values of MOi were ob- 
tained from Climatic Research Unit website (http:// www.cru.uea.ac.uk/cru/data/moi/) for the period 1951-2014. Monthly WeMOi data was obtained from the University of Barcelona webpage (http://www. ub.edu/gc/en/2016/o6/o8/wemo/) for the period 19632014. Annual AOi, EAi, EA/WRi, ENSOi, MOi, NAOi, SCANDi and WeMOi were calculated using monthly series, while annual MOi was calculated using daily series.

The obtained data were analyzed in a statistical program SPSS. Data were analyzed for the whole research period 1951-2014 and for the moving three-decade periods: 1951-1980, 1961-1990, 1971-2000 and 19812010. Three-decade period is minimum relevant for climatologic and hydrologic analysis according to World Meteorological Organization. Presented results were obtained using statistical analyses applied in similar researches: descriptive statistical analysis (Maguire \& Klobučar, 2011), one-way analysis of variance (ANOVA) (Xiaolong et al., 2010; Parvulescu et al., 2011; Paillisson et al., 2011; Ntakirutimana et al., 2013; Pantelić et al., 2012) and t-test analysis for independent samples (Leščešen et al., 2015). Post-hoc Scheffe test was applied for definition of difference significance between certain groups (Banha \& Anastacio, 2011; Leščešen et al., 2015). Descriptive statistical anal- ysis was applied for the definition of parameters mean values according to rivers, profiles and time periods. One-way analysis of variance is statistical procedure that ensures difference testing between several arithmetic means. Post-hoc Scheffe test: If F-test proves there are statistically significant differences, it is important to define the groups among which there are statistically significant differences. The results of Ftest can only prove the significance of the difference between groups with the lowest and highest arithmetic means. Different significance between particular groups can be defined according to post-hoc test, i.e. technique for systematic error risk lessening, whereas the error can be caused by greater number of comparisons between two arithmetic means. Scheffe post-hoc test, as one of the strictest and most often applied tests (Augustus et al., 2002; Yang et al., 2002), was used in this research. T-test for independent samples is widely used for comparison of results and definition of statistical significance of differences between mean values of investigated parameters. Independent samples are samples that do not have any correlation after the measurement (Baldi \& Long, 2001). Risk possibility level of $5 \%$ and $1 \%$ (Yang et al., 2002) was taken into account in the process of definition of statistical significance of obtained results.

\section{Results and discussion}

During the studied period (1951-2014) average annual discharge $\left(\mathrm{Q}_{\text {avg }}\right)$ was $2.286 \mathrm{~m}^{3} / \mathrm{s}$. Highest annual discharge value was recorded during $1980\left(3.775 \mathrm{~m}^{3} / \mathrm{s}\right)$. Average monthly values show that the discharge was highest $\left(2.960 \mathrm{~m}^{3} / \mathrm{s}\right)$ during June while lowest was during October $\left(1.705 \mathrm{~m}^{3} / \mathrm{s}\right)$. The annual $\mathrm{Q}_{\mathrm{avg}}$ values presented in figure 2 clearly shows moderate negative trend $(y=-0.332 x+2297)$. Presented decreases in discharge values are in good accordance with results presented by Arnell and Gosling (2013) and Schnider et al (2013) which projected a decrease in discharge of the major rivers in the Central and Southern Europe. During 1951-1980 period $Q_{\text {avg }}$ was $2.359 \mathrm{~m}^{3} / \mathrm{s}$, with highest average monthly discharge in July, $3.086 \mathrm{~m}^{3} / \mathrm{s}$ and lowest during October $\left(1.677 \mathrm{~m}^{3} / \mathrm{s}\right)$ with trend during observed period $(2.645 \mathrm{x}+2318)$. During 1961-1990 period $\mathrm{Q}_{\text {avg }}$ was $2.295 \mathrm{~m}^{3} / \mathrm{s}$ with highest discharge value in $1980\left(3.775 \mathrm{~m}^{3} / \mathrm{s}\right)$. Negative trend was observed during this period $(y=-6.014 x+2387)$. In third thirty-year period (1971-2000), annual $Q_{\text {avg }}$ was $2.222 \mathrm{~m}^{3} / \mathrm{s}$, with highest annual $Q_{\text {avg }}$ measured, as in the previous periods, in 1980. The highest monthly $\mathrm{Q}_{\mathrm{avg}}$ was shifted from June to May $\left(2.760 \mathrm{~m}^{3} / \mathrm{s}\right)$ while the lowest discharge values remained during October $\left(1.610 \mathrm{~m}^{3} / \mathrm{s}\right)$. In this period, positive trend was observed $(\mathrm{y}=6.290 \mathrm{x}+$
2124). During 1981-2010 three-decade period, $Q_{a v g}$ was $2.266 \mathrm{~m}^{3} / \mathrm{s}$, while the highest monthly $\mathrm{Q}_{\mathrm{avg}}$ was once again shifted, this time to April with $2.981 \mathrm{~m}^{3} / \mathrm{s}$. Highest annual $\mathrm{Q}_{\text {avg }}$ was measured in 2010 with $2.821 \mathrm{~m}^{3} / \mathrm{s}$. Very distinctive positive trend is observed during this period $(y=12.14 \mathrm{X}+2078)$. While discharge values for the 64 year period show decreasing trend, a positive trend that lasts from the seventies can be identified. This trend was also noticed on Danube River at Beuron gauging station in Germany (Caspary, 1995).

During the whole investigated period (1951-2014), average annual maximum discharge $\left(\mathrm{Q}_{\max }\right)$ was 3.078 $\mathrm{m}^{3} / \mathrm{s}$. The lowest value of $Q_{\max }$ was measured during winter $2.650 \mathrm{~m}^{3} / \mathrm{s}$, while the highest discharge was during summer $3.658 \mathrm{~m}^{3} / \mathrm{s}$. The highest annual $\mathrm{Q}_{\max }$ was in 1965 with $4.364 \mathrm{~m}^{3} / \mathrm{s}$ which was the year of biggest floods on Danube River during XX century. Average maximum monthly values show that highest discharge was measured during July $\left(3.884 \mathrm{~m}^{3} / \mathrm{s}\right)$. Highest $\mathrm{Q}_{\max }$ was measured in June of 2013 with $8.380 \mathrm{~m}^{3} / \mathrm{s}$. The annual $\mathrm{Q}_{\max }$ trend presented on figure 3 shows moderate positive trend $(y=1,897 \mathrm{x}+3016)$.

During the 1951-1980 three-decade period, average annual $\mathrm{Q}_{\max }$ was $3.061 \mathrm{~m}^{3} / \mathrm{s}$. The lowest seasonal $\mathrm{Q}_{\max }$ was during autumn $\left(2.457 \mathrm{~m}^{3} / \mathrm{s}\right)$, and highest 


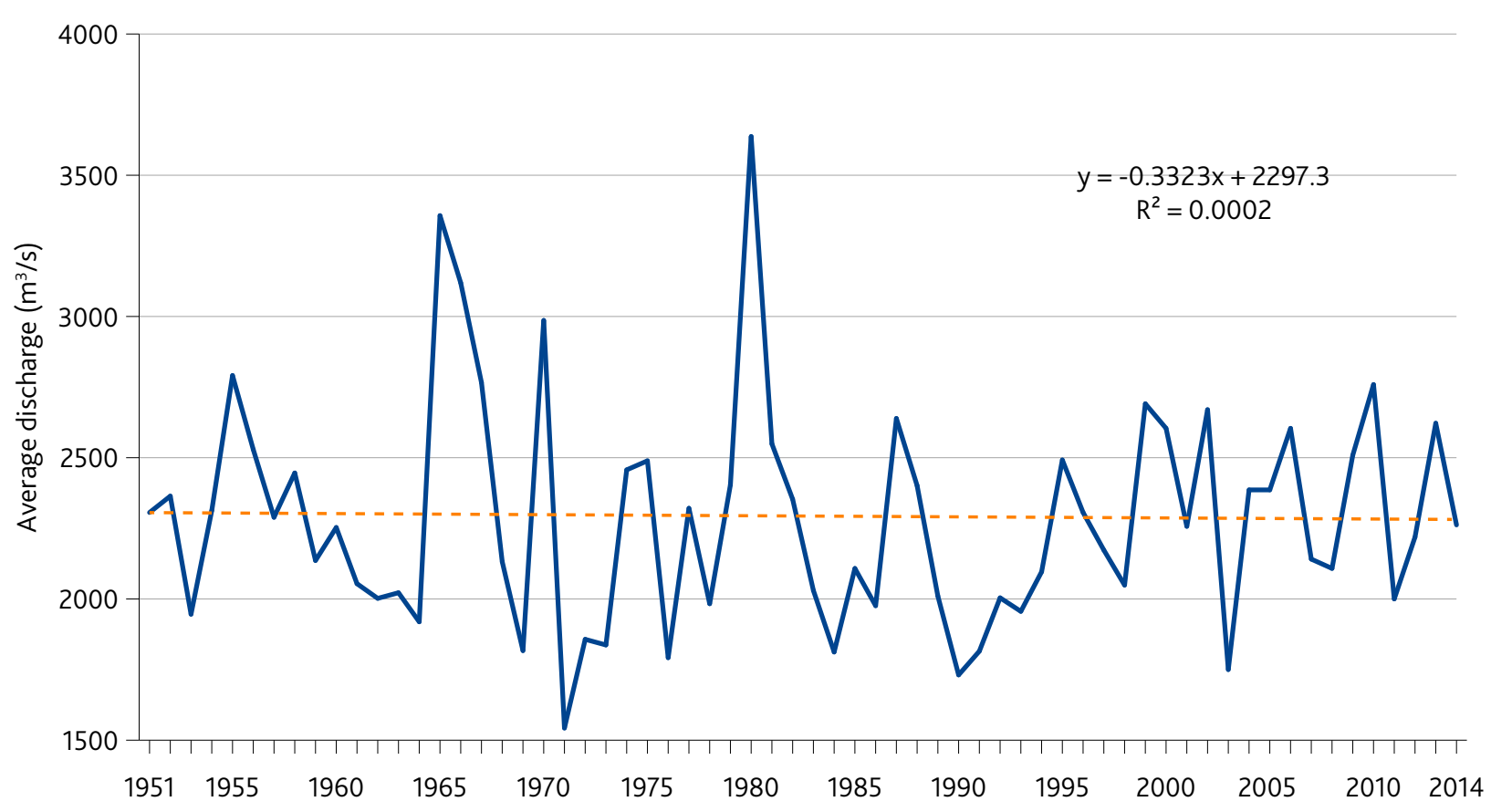

Figure 2. Average annual discharge for the 1951-2014 period

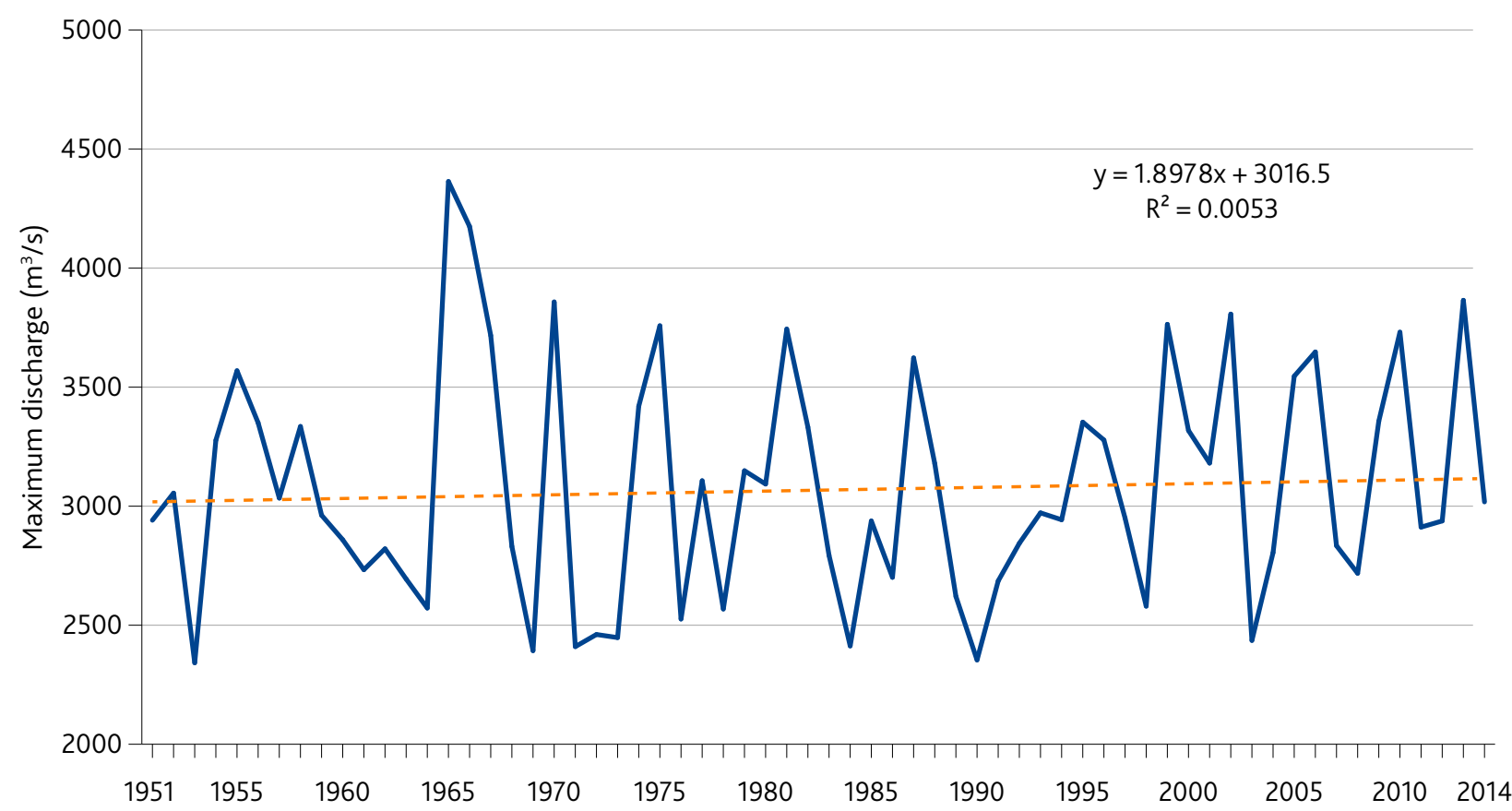

Figure 3. Average annual maximum discharge values for the 1951-2014 period

during summer $\left(3.794 \mathrm{~m}^{3} / \mathrm{s}\right)$. On monthly bases, the highest $\mathrm{Q}_{\max }$ for the observed period was during July $4.019 \mathrm{~m}^{3} / \mathrm{s}$. Annual $\mathrm{Q}_{\max }$ values show negative trend $(y=-2.813 x+3104)$ over this thirty year period. During the 1961-1990 three-decade period, average annual $\mathrm{Q}_{\max }$ was $3.026 \mathrm{~m}^{3} / \mathrm{s}$, lowest seasonal values were observed during autumn $\left(2.463 \mathrm{~m}^{3} / \mathrm{s}\right)$ while the highest were during summer $\left(3.598 \mathrm{~m}^{3} / \mathrm{s}\right)$. On monthly bases the highest values were during July $\left(3.667 \mathrm{~m}^{3} / \mathrm{s}\right)$. During this period, negative trend was also observed $(y=-$ 9.100x + 3167). For the 1971-200o period, lowest values of annual average $Q_{\max }$ was measured (2.977 $\left.\mathrm{m}^{3} / \mathrm{s}\right)$ with a maximum discharge measured in 1999 with $3.764 \mathrm{~m}^{3} / \mathrm{s}$. This is due to the fact that in this period, the 1965 flood event was not included. Again, the lowest monthly $\mathrm{Q}_{\max }$ was measured during autumn (2.413 $\left.\mathrm{m}^{3} / \mathrm{s}\right)$ and highest was during summer $\left(3.500 \mathrm{~m}^{3} / \mathrm{s}\right)$ with the highest average value of $\mathrm{Q}_{\max }$ during July $3.636 \mathrm{~m}^{3} / \mathrm{s}$. Annual $\mathrm{Q}_{\max }$ values show clear positive trend over this period $(y=9.406 x+2831)$. In the last 
thirty-year period (1981-2010) average annual $\mathrm{Q}_{\max }$ was highest among all four thirty-year periods with $3.082 \mathrm{~m}^{3} / \mathrm{s}$. Highest annual $Q_{\max }$ was during 2002 with $3.807 \mathrm{~m}^{3} / \mathrm{s}$. Highest seasonal $Q_{\max }$ was during summer $3545 \mathrm{~m}^{3} / \mathrm{s}$ and lowest during autumn $\left(2.573 \mathrm{~m}^{3} / \mathrm{s}\right)$. The highest $\mathrm{Q}_{\max }$ was during July $3.868 \mathrm{~m}^{3} / \mathrm{s}$. For this last investigated period positive trend in annual $\mathrm{Q}_{\max }$ was also clearly shown $(10.82 \mathrm{x}+2913)$. Regarding monthly $Q_{\max }$ values for all investigated periods lowest values of discharge were during the month of November while highest values were measured during the month of June. As presented, during the last two periods (1971-200o and 1981-2010) an increasing trend of $\mathrm{Q}_{\max }$ can be observed. The increasing trends were noticed on Sava River, at the geographically close locations (Jasenovac and Županja) to our investigated station (Orešić et al., 2017).

Average annual precipitation over the whole investigated period was $606 \mathrm{~mm}$ with a moderate positive upward trend $(y=0.798 x+580.2)$. Absolute maximum was measured during 2010 with $1.036 \mathrm{~mm}$. Highest amount of monthly average precipitation was measured in June with $77.1 \mathrm{~mm}$. During the first three-decade period, average amount of precipitation was 602 $\mathrm{mm}$ with no statistically significant trend over observed period (0.041x +601.6$)$. Absolute maximum of precipitation was measured in 1955 with $912 \mathrm{~mm}$ and with maximum in June $(77 \mathrm{~mm})$. Over the next three-decade period (1961-1990), average annual precipitation was lower $(583 \mathrm{~mm})$ with a clear negative trend $(y=-2.543 \mathrm{x}+622.9)$. In 1963 maximum amount of precipitation was measured $(846 \mathrm{~mm})$ with maxi- mum also in June $(79 \mathrm{~mm})$. During the period 19712000 , average annual precipitation was $580 \mathrm{~mm}$ with maximum in $1999(779 \mathrm{~mm})$ followed with minimum amount in $2000(278 \mathrm{~mm})$. Monthly value analysis show that highest amount of precipitation was in June with $76 \mathrm{~mm}$. Trend analysis show that there was no trend over this period $(y=0.083 x+578.2)$. Last threedecade period shows highest annual amount of precipitation with $612 \mathrm{~mm}$ with a clear positive trend $(y=6.354 x+513.6)$. Similar clear positive trends have been detected in several studies conducted in the UK (Osborn et al., 200o), the USA (Karl \& Knight, 1998) and Italy (Brunetti et al., 200o). Absolute maximum with $1.036 \mathrm{~mm}$ occurred in 2010, while monthly values show that highest amount of precipitation was again during June with $81.5 \mathrm{~mm}$.

Independent sample T-test was applied in order to compare arithmetic means of two groups - parameter (Pantelić et al., 2012; Leščešen et al., 2015) values with eight indices of the atmospheric circulation patterns. Results of t-test analysis for the research period are presented in Tables 1 and 2. The results obtained for all eight atmospheric circulation patterns and precipitation show that correlation values with average discharge and maximum discharge are as expected, different during research period.

Pearson correlation between $\mathrm{Q}_{\text {avg }}$, selected atmospheric oscillations indices and precipitation show variations through research period. For the whole research period 1951-2014 correlation was statistically significant for $\mathrm{Q}_{\mathrm{avg}}$ and precipitation at the level of $\mathrm{p}<0.01(\mathrm{~F}=0.226, \mathrm{p}=0.000)$. The same level of statis-

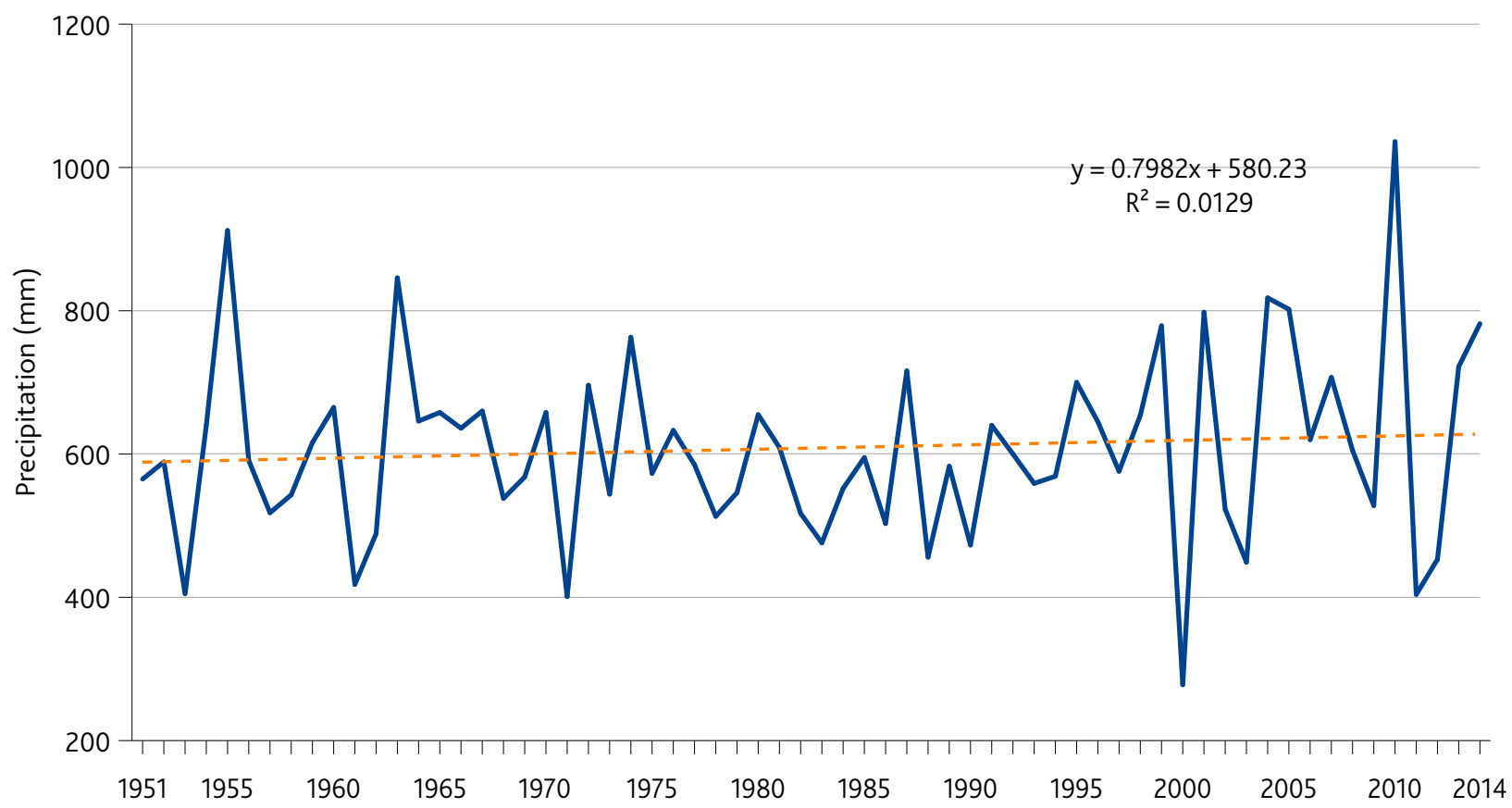

Figure 4. Annual amount of precipitation for the 1951-2014 period 
Table 1. Correlation between $\mathrm{Q}_{\mathrm{avg}}$ and selected atmospheric oscillations indices and precipitation

\begin{tabular}{|c|c|c|c|c|c|c|c|c|}
\hline \multirow{2}{*}{$\begin{array}{l}\text { Investigated } \\
\text { period }\end{array}$} & \multicolumn{2}{|c|}{ NAO } & \multicolumn{2}{|c|}{$\mathrm{AOI}$} & \multicolumn{2}{|c|}{ ENSO } & \multicolumn{2}{|c|}{ EA/WRi } \\
\hline & $r$ & $P$ & $r$ & $P$ & $r$ & $P$ & $r$ & P \\
\hline $1951-2014$ & $-0,025$ & 0,481 & $-0,037$ & 0,303 & 0,012 & 0,746 & 0,019 & 0,595 \\
\hline 1951-1980 & 0,012 & 0,825 & 0,024 & 0,648 & 0,054 & 0,308 & 0,059 & 0,262 \\
\hline 1961-1990 & 0,000 & 1,000 & $-0,012$ & 0,815 & 0,105 & $0,046^{*}$ & 0,033 & 0,535 \\
\hline $1971-2000$ & $-0,020$ & 0,704 & $-0,098$ & 0,063 & 0,016 & 0,759 & $-0,054$ & 0,303 \\
\hline 1981-2010 & $-0,050$ & 0,342 & $-0,085$ & 0,107 & $-0,064$ & 0,228 & $-0,066$ & 0,209 \\
\hline \multirow{2}{*}{$\begin{array}{l}\text { Investigated } \\
\text { period }\end{array}$} & \multicolumn{2}{|c|}{ EAOI } & \multicolumn{2}{|c|}{ SCANDi } & \multicolumn{2}{|c|}{ MOI } & \multicolumn{2}{|c|}{ WeMOI } \\
\hline & $r$ & $\mathrm{P}$ & $r$ & $\mathrm{P}$ & $r$ & $\mathrm{P}$ & $r$ & $P$ \\
\hline 1951-2014 & 0,067 & 0,062 & 0,026 & 0,466 & 0,172 & $0,000 * *$ & 0,145 & $0,000 * *$ \\
\hline 1951-1980 & 0,091 & 0,085 & 0,032 & 0,543 & 0,232 & $0,001 * *$ & 0,210 & $0,002^{* *}$ \\
\hline 1961-1990 & 0,048 & 0,360 & 0,045 & 0,396 & 0,201 & $0,000 * *$ & 0,177 & $0,001^{* *}$ \\
\hline $1971-2000$ & 0,066 & 0,214 & 0,034 & 0,522 & 0,142 & $0,007^{* *}$ & 0,132 & $0,012^{* *}$ \\
\hline 1981-2010 & 0,061 & 0,245 & 0,008 & 0,884 & 0,122 & $0,020 *$ & 0,061 & 0,252 \\
\hline
\end{tabular}

${ }^{* *} p<0.01 ;{ }^{*} p<0.05$;

tical correlation between $\mathrm{Q}_{\mathrm{avg}}$ and precipitation has been retained to the same extent of $\mathrm{p}<0.01$ in the moving three-decade periods: 1951-1980 ( $\mathrm{F}=0.203$, $\mathrm{p}=0.000), 1961-1990 \quad(\mathrm{~F}=0.197, \mathrm{p}=0.000), 1971-2000$ $(\mathrm{F}=0.167, \mathrm{p}=0.002)$ and 1981-2010 $(\mathrm{F}=0.276, \mathrm{p}=0.000)$. This strong correlation between precipitation and river discharge was observed in multiple European regions (Dettinger \& Diaz, 2000; Ionita \& Rimbu, 2008). In 1961-1990 three-decade period, significant correlation at the level $\mathrm{p}<0.05$ was registered between $\mathrm{Q}_{\mathrm{avg}}$ and ENSOi $(\mathrm{F}=0.105, \mathrm{p}=0.046)$. Significant correlation at the level $\mathrm{p}<0.01$ was registered for the whole researched period 1951-2014 between $Q_{\text {avg }}$ and MOi $(\mathrm{F}=0.172, \mathrm{p}=0.000)$ and WeMOi $(\mathrm{F}=0.145, \mathrm{p}=0.000)$. Correlation between $\mathrm{Q}_{\mathrm{avg}}$ and $\mathrm{MOi}$ varies in the three-decade moving periods, in 1951-1980 ( $\mathrm{F}=0.232$, $\mathrm{p}=0.001), 1961-1990(\mathrm{~F}=0.201, \mathrm{p}=0.000)$ and 1971-2000 $(\mathrm{F}=0.142, \mathrm{p}=0.007)$ being at the level $\mathrm{p}<0.01$; follows 1981-2010 three-decade period with correlation level at $\mathrm{p}<0.05(\mathrm{~F}=1.122, \mathrm{p}=0.020)$. Same level of statistical correlation of $\mathrm{p}<0.01$ between $\mathrm{Q}_{\mathrm{avg}}$ and WeMOi has been retained in the two moving three-decade periods, 1951-1980 ( $\mathrm{F}=0.210, \mathrm{p}=0.002), 1961-1990(\mathrm{~F}=0.177$, $\mathrm{p}=0.001)$ and in the $1971-2000$ correlation is at level $\mathrm{p}<0.05(\mathrm{~F}=0.132, \mathrm{p}=0.012)$.

Pearson correlation between $\mathrm{Q}_{\max }$ and selected atmospheric oscillations indices and precipitation show variations through researched period. For the whole researched period 1951-2014 correlation is statistically significant for $\mathrm{Q}_{\max }$ and precipitation at the level of $\mathrm{p}<0.01(\mathrm{~F}=0.158, \mathrm{p}=0.000)$. Same level of statistical correlation between $\mathrm{Q}_{\max }$ and precipitation has been

Table 2. Correlation between $\mathrm{Q}_{\max }$ and selected atmospheric oscillations indices and precipitation

\begin{tabular}{|c|c|c|c|c|c|c|c|c|}
\hline \multirow{2}{*}{$\begin{array}{l}\text { Investigated } \\
\text { period }\end{array}$} & \multicolumn{2}{|c|}{ NAO } & \multicolumn{2}{|c|}{$\mathrm{AOI}$} & \multicolumn{2}{|c|}{ ENSO } & \multicolumn{2}{|c|}{ EA/WRi } \\
\hline & $r$ & $P$ & $r$ & $P$ & $r$ & $P$ & $r$ & $P$ \\
\hline 1951-2014 & $-0,036$ & 0,318 & 0,001 & 0,986 & $-0,042$ & 0,244 & 0,059 & 0,100 \\
\hline 1951-1980 & $-0,015$ & 0,780 & 0,069 & 0,192 & $-0,042$ & 0,427 & 0,126 & 0,017 \\
\hline 1961-1990 & 0,013 & 0,805 & 0,040 & 0,444 & 0,037 & 0,482 & 0,096 & 0,068 \\
\hline 1971-2000 & 0,024 & 0,651 & $-0,023$ & 0,666 & $-0,043$ & 0,421 & 0,015 & 0,775 \\
\hline 1981-2010 & $-0,060$ & 0,254 & $-0,058$ & 0,254 & $-0,042$ & 0,422 & $-0,038$ & 0,476 \\
\hline \multirow{2}{*}{$\begin{array}{l}\text { Investigated } \\
\text { period }\end{array}$} & \multicolumn{2}{|c|}{ EAOI } & \multicolumn{2}{|c|}{ SCANDi } & \multicolumn{2}{|c|}{ MOI } & \multicolumn{2}{|c|}{ WeMOI } \\
\hline & $r$ & $P$ & $r$ & $P$ & $r$ & $P$ & $r$ & $P$ \\
\hline 1951-2014 & 0,085 & $0,018^{*}$ & 0,045 & 0,215 & 0,239 & $0,000 * *$ & 0,054 & 0,182 \\
\hline 1951-1980 & 0,067 & 0,208 & $-0,018$ & 0,735 & 0,354 & $0,000 * *$ & 0,175 & $0,010 *$ \\
\hline 1961-1990 & 0,025 & 0,637 & $-0,014$ & 0,791 & 0,314 & $0,000 * *$ & 0,123 & $0,024 *$ \\
\hline 1971-2000 & 0,090 & 0,090 & 0,047 & 0,376 & 0,251 & $0,000 * *$ & 0,044 & 0,401 \\
\hline 1981-2010 & 0,101 & 0,056 & 0,089 & 0,093 & 0,167 & $0,001^{* *}$ & $-0,031$ & 0,555 \\
\hline
\end{tabular}


retained at level of $\mathrm{p}<0.01$ in the moving three-decade periods: $1951-1980(\mathrm{~F}=0.161, \mathrm{p}=0.002), 1961-1990$ $(\mathrm{F}=0.142, \mathrm{p}=0.007)$ and 1981-2010 $(\mathrm{F}=0.153, \mathrm{p}=0.004)$. During the 1971-2000 correlation is at level of $\mathrm{p}<0.05$ $(\mathrm{F}=0.127, \mathrm{p}=0.016)$. Statistical correlation for the whole research period 1951-2014 is registered at the level of $\mathrm{p}<0.05(\mathrm{~F}=0.085, \mathrm{p}=0.018)$ between $\mathrm{Q}_{\max }$ and the $\mathrm{EAi}$ and at the level of $\mathrm{p}<0.01(\mathrm{~F}=0.239, \mathrm{p}=0.000)$ between $\mathrm{Q}_{\max }$ and the MOi. In the three-decade moving periods statistical correlations are registered at the level $\mathrm{p}<0.01$ between $\mathrm{Q}_{\max }$ and the MOi, 1951-1980 $(\mathrm{F}=0.354$, $\mathrm{p}=0.000), 1961-1990 \quad(\mathrm{~F}=0.314, \mathrm{p}=0.000), 1971-2000$
$(\mathrm{F}=0.251, \mathrm{p}=0.000)$ and 1981-2010 $(\mathrm{F}=0.167, \mathrm{p}=0.001)$. In the two three-decade moving periods are registered statistical correlations between $\mathrm{Q}_{\max }$ and the WeMOi at the level of $\mathrm{p}<0.05$ in 1951-1980 $(\mathrm{F}=0.175, \mathrm{p}=0.010)$ and $1961-1990(\mathrm{~F}=0.123, \mathrm{p}=0.024)$. Interesting observation is that NAO show no statistically significant correlation with discharge values on our site, this result is in contrast with results that were previously presented by Rimbu et al. (2004) and Mikhailova et al. (2008). Our results show that MOI have dominant influence on Danube River discharge at Bezdan station at the highly significance level $(\mathrm{p}=0,000$ and $\mathrm{p}=0,001)$.

\section{Conclusion}

During the whole investigated period (1951-2014), $Q_{a v g}$ on Danube River Bezdan gauging station is $2.286 \mathrm{~m}^{3} / \mathrm{s}$ and average monthly values show that highest $Q_{a v g}$ is measured during June with $2.960 \mathrm{~m}^{3} / \mathrm{s}$. Average annual $Q_{\max }$ is $3.078 \mathrm{~m}^{3} / \mathrm{s}$, lowest average monthly $Q_{\max }$ is in December $2.650 \mathrm{~m}^{3} / \mathrm{s}$ and the highest is in June $3.658 \mathrm{~m}^{3} / \mathrm{s}$.

Average annual precipitation over the whole investigated period is $606 \mathrm{~mm}$ with a highest average monthly amount of precipitation measured in June $(77.1 \mathrm{~mm})$. During the whole period, $\mathrm{Q}_{\mathrm{avg}}$ shows moderate negative trend while $\mathrm{Q}_{\max }$ and precipitation show positive trends. In conclusion, the observed river discharge regime changes are unfavourable from the hydrological stand point and as such these changes should be considered by experts in different fields, because, most likely current discharge trends will continue in accordance to predicted future climate change in the region. Correlations between atmospheric circulation patterns, precipitation and Danube River flow in Central Danube River basin were analyzed and general results are acquired. The results suggest predominant positive influence of precipitation on $\mathrm{Q}_{\mathrm{avg}}$ and on $\mathrm{Q}_{\max }$. Positive influence of MOi and WeMOi on $\mathrm{Q}_{\mathrm{avg}}$ is registered for the whole period 1951-2014 and in all moving three-decade periods except for WeMOi in 1981-2010. The majority of registered correlations are at the level of $\mathrm{p}<0.01$. Also, in one tree-decade period 1961-1990 is registered positive influence of ENSOi on $\mathrm{Q}_{\mathrm{avg}}$ at the level of $\mathrm{p}<0.05$. On $\mathrm{Q}_{\max }$ positive influence through the whole period and in all moving three-decade periods have precipitation with dominant level at $\mathrm{p}<0.05$. Constant positive influence on $\mathrm{Q}_{\max }$ for the whole period and in all moving three-decade periods was registered. From MOi at the level of $\mathrm{p}<0.01$. For the whole period is registered $\mathrm{EAi}$ influence on $\mathrm{Q}_{\max }$ with level of $\mathrm{p}<0.05$. And in the two moving three-decade periods (1951-1980 and 1961-1990) the positive influence of WeMOi on $\mathrm{Q}_{\max }$ on the level of $\mathrm{p}<0.05$ was registered. All registered correlations are positive.

We can conclude that average and maximum discharge values of the Danube River at the Bezdan station are correlated with eight atmospheric circulation patterns indices: AOi, EAi, EA/WRi, ENSOi, MOi, NAOi, SCANDi and WeMOi. Average river discharge is influenced dominantly by precipitation, MOi and WeMOi, while maximum discharge is under the influence only by precipitation and MOi.

Despite the evidence on the appropriateness of the $\mathrm{NAO}$ as an indicator of the climate in Europe we suggest that by using a MOi or WeMOi a more accurate and reliable forecasting of the average and maximum discharges for Danube River. Future research will be set towards establishing the physical mechanisms that is responsible for the MOi and WeMOi impact on Danube discharge as presented in our study.

\section{References}

Augustus, S.P.D.G., Jayabalan, M.. \& Seiler, J. G. (2002). Evaluation and bioinduction of energy components of Jatropha curca. Biomass and Bioenergy 23(3), 161164. https://doi.org/10.1016/So961-9534(o2)0oo44-2

Arnell, N. W., \& Gosling, S. N. (2013). The impacts of climate change on river flow regimes at the glob- al scale. Journal of Hydrology 486, 351-364. http:// dx.doi.org/10.1016/j.jhydrol.2013.02.010.

Baldi, P. \& Long, D. A. (2001). A Bayesian framework for the analysis of microarray expression data: regularized t-test and statistical inferences of gene changes. Bioinformatics 17(6), 509-519. https://doi. org/10.1093/bioinformatics/17.6.509 
Banha, F. \& Anastacio P.M. (2011). Interactions between invasive crayfish and native river shrimp. Knowledge and Management of Aquatic Ecosystems 401(17). https://doi.org/10.1051/kmae/2011033

Bomin, S. \& Shuqing, S. (1994). The analysis on the features of the atmospheric circulation in preceding winters for the summer drought and flooding in the Yangtze and Huaihe river valley. Advances in Atmospheric Sciences 11(1), 79-90. https://doi. org/10.1007/BFo2656997

Brunetti, M., Buffoni, L., Maugeri, M., \& Nanni, T. (200o). Precipitation intensity trends in northern Italy. International Journal of Climatology: A Journal of the Royal Meteorological Society, 20(9), 10171031.

Caspary, H. J. (1995). Recent winter floods in Germany caused by changes in the atmospheric circulation across Europe. Physics and Chemistry of the Earth, 20(5-6), 459-462. https://doi.org/10.1016/ Soo79-1946(96)oooo6-7

Dettinger, M.D., \& Diaz, H.F. (200o). Global characteristics of streamflow seasonality. Journal of $\mathrm{Hy}$ drometeorology, 1(4), 289-310.

Gosling, S.N., Zaherpour, J.J., Mount, N.J., Hattermann, F.F., Dankers, R., Arheimer, B., Breuer, L., Ding, J., Haddeland, I., Kumar, R., Kundu, D., Liu, J., van Griensven, A., Veldkamp, T.I.E., Vetter, T., Wang, X. \& Zhang, X. (2017). A comparison of changes in river runoff from multiple global and catchment-scale hydrological models under global warming scenarios of $1 \mathrm{C}, 2 \mathrm{C}$ and $3 \mathrm{C}$. Climatic Change, 141(3), 577-595. http://dx.doi.org/10.1007/ S10584-016-1773-3.

Hurrell, J. W., Kushnir, Y., \& Ottersen, G. (2003). An overview of the North Atlantic oscillation. In J.W. Hurrell, Y. Kushnir, G. Ottersen, M. Visbeck, \& M.H. Visbeck (Eds.), The North Atlantic Oscillation: Climatic Significance and Environmental Impact, Geophysical Monograph Series (pp. 1-35), Washington: American Geophysical Union. doi:10.1029/134GMo1.

Kingston, D. G., Todd, M. C., Taylor, R. G., Thompson, J. R., \& Arnell, N. W. (2009). Uncertainty in the estimation of potential evapotranspiration under climate change. Geophysical Research Letters, 36(20).

Kundzewicz, Z.W., Mata, L.J., Arnell, N., Döll, P., Kabat, P., Jiménez, B., Miller, K., Oki, T., Şen, Z. \& Shiklomanov, I. (2007). Freshwater resources and their management. In M. L. Parry, O. F. Canziani, J. P. Palutikof, P. J. van der Linden \& C. E. Hanson (Eds.), Climate Change 2007: Impacts, Adaptation and Vulnerability. Contribution of Working Group II to the Fourth Assessment Report of the Intergovernmental Panel on Climate Change (pp. 173-210). UK: Cambridge University Press.
Ionita, M., Lohmann, G., \& Rimbu, N. (2008). Prediction of spring Elbe discharge based on stable teleconnections with winter global temperature and precipitation. Journal of Climate, 21(23), 6215-6226. DOI:10.1175/2008JCLI2248.1.

Karl, T. R., \& Knight, R. W. (1998). Secular trends of precipitation amount, frequency, and intensity in the United States. Bulletin of the American Meteorological society, 79(2), 231-242.

Lavers, D. A., Allan, R. P., Wood, E. F., Villarini, G., Brayshaw, D. J., \& Wade, A. J. (2011). Winter floods in Britain are connected to atmospheric rivers. $\mathrm{Ge}$ ophysical Research Letters, 38(23).

Leščešen, I., Pantelić, M., Dolinaj, D., Stojanović, V. \& Milošević, D. (2015). Statistical analysis of Water Quality Parameters of the Drina River (West Serbia), 2004-2011, Polish Journal of Environmental Studies 24 (2), 555-561. https://doi.org/10.15244/ pjoes $/ 29684$

Osborn, T. J., Hulme, M., Jones, P. D., \& Basnett, T. A. (2000). Observed trends in the daily intensity of United Kingdom precipitation. International Journal of Climatology, 20(4), 347-364.

Ntakirutimana, T., Du, G., Guo, J. S., Gao, X., \& Huang, L. (2013). Pollution and Potential Ecological Risk Assessment of Heavy Metals in a Lake. Polish Journal of Environmental Studies, 22(4), 1129-1134.

Wedgbrow, C. S., Wilby, R. L., Fox, H. R., \& O'hare, G. (2002). Prospects for seasonal forecasting of summer drought and low river flow anomalies in England and Wales. International Journal of Climatology, 22(2), 219-236. https://doi.org/10.1002/joc.735

Pantelić, M., Dolinaj, D., Savić, S., Stojanović, D. \& Nađ, I. (2012). Statistical Analysis of water quality parameters of Veliki Bački Canal (Vojvodina, Serbia) in period 2000-2009, Carpathian Journal of Earth and Environmental Sciences, 7 (2), 255.

Paillisson, J.M., Soudieux, A. \& Damien, J.P. (2011). Capture efficiency and size selectivity of sampling gears targeting red-swamp crayfish in several freshwater habitats, Knowledge and Management of Aquatic Ecosystems 401 (o6). https://doi.org/10.1051/ $\mathrm{kmae} / 2011015$

Parvulescu, L., Pacioglu, O. \& Hamchevici, C. (2011). The assessment of the habitat and water quality requirements of the stone crayfish (Austropotamobiustorrentium) and noble crayfish (Astacusastacus) species in the rivers from the Anina Mountains (SW Romania), Knowledge and Management of Aquatic Ecosystems 401 (03). https://doi.org/10.1051/ $\mathrm{kmae} / 2010036$

Peterson, J.B., Holmes, M.R., McClelland, W.J., Vorosmarty, J.C., Lammers, B.R., Shiklomanov, I.A. \& Rahmstorf, S. (2002). Increasing River Discharge 
to the Arctic Ocean, Science 298 (5601), 2171-2173. DOI: $10.1126 /$ science.1077445

Peterson, H.D. (2013). Aspects of Climate Variability in the Pacific and the Western Americas. American Geophysical Union. DOI:10.1002/9781118664285

Rimbu, N., Boroneant, C., Buta, C. \& Dima, M. (2002). Decadal variability of the Danube river flow in the lower basin and its relation with the North Atlantic Oscillation, International Journal of Climatology 22, 1169-1179. DOI:10.1002/joc.788

Rimbu, N., Dima, M., Lohmann, G., \& Stefan, S. (2004). Impacts of the North Atlantic Oscillation and the El Nin $\sim 0-$ Southern Oscillation on Danube river flow variability, Geophysical Research Letters 31 (23). doi:10.1029/2004GL020559

Maguire, I., \& Klobučar, G. (2011). Size structure, maturity size, growth and condition index of stone crayfish (Austropotamobiustorrentium) in North-West Croatia, Knowledge and Management of Aquatic Ecosystems 401 (12). https://doi.org/10.1051/kmae/2011026

Milošević, D., Savić, S., Pantelić, M., Stankov, U., Žiberna, I., Dolinaj, D. \& Leščešen, I. (2015). Variability of seasonal and annual precipitation in Slovenia and its correlation with large-scale atmospheric circulation, Open Geosciences 8, 593-605. DOI 10.1515/geo-2016-0041

Milošević, D., Savić, S., Stankov, U., Žiberna, I., Pantelić, M., Dolinaj, D. \& Leščešen, I. (2017). Maximum temperatures over Slovenia and their rela- tionship with atmospheric circulation patterns, $\mathrm{Ge}$ ografie 122 (1), 1-20.

Murphy, S. J., \& Washington, R. (2001). United Kingdom and Ireland precipitation variability and the North Atlantic sea-level pressure field. International Journal of Climatology: A Journal of the Royal Meteorological Society, 21(8), 939-959. https://doi. org/10.1002/joc.670

Uvo, B.C. (2003). Analysis and regionalization of northern European winter precipitation based on its relationship with the North Atlantic oscillation, International Journal of Climatology 23, 10, 11851194. DOI: 10.1002/joc.930

Xiaolong, W., Jingyi, H., Ligang, X. \& Qi, Z. (2010). Spatial and seasonal variations of the contamination within water body of the Grand Canal, China, Environmental Pollution 158 (5), 1513-1520. DOI: 10.1016/j.envpol.2009.12.018

Yang, C.Y., Lee, G.S., Lee, K.H., Kim, K.M. \& Lee, H.S. (2002). A Piperidine Amide Extracted from Piper longum L. Fruit Shows Activity against Aedes aegypti Mosquito Larvae, Jornal of Agricultural and Food Chemistry 50 (13), 3765-3767. DOI: 10.1021/ jfo11708f

https://www.cpc.ncep.noaa.gov/products/precip/ CWlink/daily_ao_index/teleconnections.shtml http://www.ub.edu/gc/en/2016/o6/o8/wemo/ http://www.cru.uea.ac.uk/cru/data/moi/ 